\title{
METODE TERAPI HIPNOPUNKTUR (HIPNOTERAPI DAN TERAPI AKUPUNKTUR) UNTUK PENINGKATAN KUALITAS HIDUP PASIEN KANKER RAHIM PASCA KEMOTERAPI DI KOTA SURAKARTA
}

\author{
Maria Dewi Christiyawati, Sri Yatmihatun, Sumanto, \\ Kementerian Kesehatan Politeknik Kesehatan Surakarta Jurusan Terapi Wicara
}

\begin{abstract}
Uterine Cancer Is A Gynecologic Malignancy Is Most Common In Women, One Of Its Kind Is A Uterine Sarcoma. Uterine sarcoma is a rare tumor that dominates 3\% of uterine cancer. Myoma uteri can cause malignancy although his case is rare. In Indonesia, the proportion of myoma uteri reach 2.39 to $11.7 \%$ of all gynecological patients. Chemotherapy is a treatment for uterine cancer drugs of the use of drugs to kill or slow the growth of cancer cells that can cause side effects. The side effects that can be felt by people with cancer of the uterus such as feeling sick, vomiting, feeling tired, weight loss, hair loss, loss of appetite and difficulty sleeping. Approximately 70-100\% of chemotherapy patients experience fatigue / fatigue. Fatigue felt by patients with this cancer will also affect the quality of life penderita.Terapi acupuncture in cancer patients can be done to overcome the side effects of chemotherapy either by research or classical theory. The research method was quasi experimental design with pre -post test design without control group. Data were taken before and after administration of therapeutic intervention hipnopunctur. Data dianlisis using t-test, independent $t$ test multiple linear regression. Number of samples 14 people. Results obtained significance value $(p)=0.000$ compared with the value $\alpha=0: 05(5 \%)$, where the value of $P<0.05$, which means that a significant difference between the methods Hipnopunkture with improved quality of life. Values obtained -0824 t test. The value of the coefficient is between 0.8 -1.0 interval which indicates the degree of influence between these variables is very strong.
\end{abstract}

Keywords : Uterine Sarcoma, Hipnopunctur Therapy, Quality Of Life, Symptoms Of Post - Chemotherapy

Abstrak : Sarcoma Uteri, Terapi Hipnopunktur, Kualitas Hidup, Gejala Pasca Kemoterapi. Kanker rahim merupakan keganasan ginekologi yang paling umum terjadi pada wanita, salah satu jenisnya adalah sarkoma uteri. Sarkoma uteri adalah tumor langka yang mendominasi $3 \%$ dari kanker rahim. Mioma uteri dapat menimbulkan keganasan walaupun kasusnya jarang ditemukan. Di Indonesia proporsi mioma uteri mencapai 2,39-11,7 \% dari semua penderita ginekologi. Kemoterapi merupakan salah satu terapi untuk Kanker rahim yang menggunakan obat -obatan untuk membunuh atau memperlambat pertumbuhan sel kanker yang dapat menimbulkan efek samping. Efek samping yang dapat dirasakan penderita kanker rahim seperti merasa sakit, muntah, merasa lelah, berat badan menurun, rambut rontok, kehilangan nafsu makan dan sulit tidur . Sekitar 70 - 100\% pasien kemoterapi mengalami kelelahan/ fatigue. Rasa lelah yang dirasakan penderita kanker ini juga akan mempengaruhi kualitas hidup penderita.Terapi akupunktur pada penderita kanker dapat dilakukan untuk 
mengatasi efek samping kemoterapi baik berdasarkan penelitian maupun teori klasik. Metode penelitian adalah quasi experiment dengan desain pre -post test design without control group. Data diambil sebelum dan setelah pemberian intervensi terapi hipnopunktur. Data dianlisis menggunakan $t$-test, independent $t$ test regresi linier ganda. Jumlah sampel 14 orang. Hasil didapatkan nilai signifikansi $(\mathrm{p})=0.000$ yang dibandingkan dengan nilai $\alpha=0.05(5 \%)$, dimana nilai $\mathrm{p}<0.05$, yang berarti bahwa terdapat pengaruh yang signifikan antara metode Hipnopunkture dengan peningkatan kualitas hidup. Nilai uji $t$ didapatkan -0.824 . Nilai tersebut berada diantara interval koefisien 0.8 -1.0 yang menandakan tingkat pengaruh antar variabel tersebut sangat kuat.

Kata Kunci : Sarcoma Uteri, Terapi Hipnopunktur, Kualitas Hidup, Gejala Pasca Kemoterapi

\section{PENDAHULUAN}

Kanker merupakan salah satu penyakit yang telah menjadi masalah kesehatan masyarakat baik di dunia maupun Indonesia. Menurut survei Kesehatan Rumah Tangga (SKRT) persentase angka kematian akibat kanker di Indonesia pada tahuan 1992 mencapai 4,8\%, tahun 1995 meningkat menjadi $5.0 \%$ dan tahun 2001 meningkat lagi menjadi $6.0 \%$ (Nainggolan, Maria and Marice,2009). Berdasarkan data Riskesdas 2007-2008 didapatkan resiko penyakit tumor/kanker menurut jenis kelamin lebih banyak terjadi pada perempuan dibandingkan laki - laki

Kanker rahim

merupakan keganasan ginekologi yang paling umum terjadi pada wanita, salah satu jenisnya adalah sarkoma uteri. . Sarkoma uteri adalah tumor langka yang mendominasi $3 \%$ dari kanker rahim (Naaman,et al., 2011). Wanita dengan sarkoma uteri memiliki prognosis buruk dengan kelangsungan hidup kurang dari $50 \%$ dalam 2 tahun, bahkan pada fase awal penyakit (Desnschlag,et al., 2006). Mioma uteri dapat menimbulkan keganasan (sarcoma) walaupun kasusnya jarang ditemukan. Di Indonesia, proporsi mioma uteri mencapai 2,39-11,7 \% dari semua penderita ginekologi yang dirawat di RSUD Dr. Pirngadi Medan.

Terapi yang dapat dipilih pada penderita sarkoma uteri adalah operasi, terapi radiasa dan kemoterapi (Naaman,et al., 2011). Penderita sarkoma uteri dapat menerima lebih dari satu terapi, salah satu diantaranya adalah kemoterapi. Kemoterapi merupakan terapi yang menggunakan obat -obatan untuk membunuh atau memperlambat pertumbuhan sel kanker yang dapat menimbulkan efek samping. Efek samping yang dapat dirasakan penderita kanker rahim seperti merasa sakit, muntah, merasa lelah, berat badan menurun, rambut rontok, kehilangan nafsu makan dan sulit tidur. Spichiger, et al.(2001) melaporkan sekitar 70 $100 \%$ pasien kemoterapi mengalami kelelahan/fatigue. Rasa lelah yang dirasakan penderita kanker ini juga akan mempengaruhi kualitas hidup penderita (Mahoney,et al, 2013)

Richardson dan rekannya (dalam Cohen,Menter dan Hale,2005) membagikan kuisioner kepada 453 pasien kanker dan didapatkan 83,3\% diantaranya menggunakan sedikitnya satu jenis pengobatan komplementer 
dan alternatif (CAM) untuk mengurangi nyeri, mengatasi efek samping dari kemoterapi dan radioterapi serta untuk meningkatkan kualitas hidup. Salah satu jenis pengobatan komplementer yang telah menjadi populer di kalangan pasien kanker adalah Akupunktur. Terapi Akupunktur dapat berperan dalam meningkatkan imunitas tubuh, memperpanjang waktu harapan hidup pasien dan mengatasi efek samping dari radioterapi dan kemoterapi seperti leukocyptopenia, mual, nyeri, kehilangan nafsu makan, konstipasi atau diare, insomnia, kadar $\mathrm{Hb}$ yang menurun, kecemasan sampai dengan depresi serta ketakutan akan hidup selanjutnya (Jin,Jin and Jin,2006).

Menurut Vinjamury,et al.(2013) intervensi akupunktur bermanfaat untuk mengurangi nyeri dan meningkatkan kualitas hidup (QoL) penderita kanker,Wit,et al.(2009) mengevaluasi keamanan terapi akupunktur pada 299.230 pasien kanker yang menerima pengobatan konvensional seperti kemoterapi. Hasil penelitian tersebut menunjukkan bahwa terapi akupunktur yang dilakukan oleh tenaga medis relatif aman untuk mendukung pengobatan konvensional yang dijalani oleh pasien kanker. Terapi akupunktur juga sangat relevan jika dipadukan dengan terapi relaksasi/ hipnoterapi untuk pasien pasca kemoterapi sarkoma uteri yang signifikan untuk mengatasi ketakutan dan nyeri.

Berdasarkan penjelasan tersebut, dapat disimpulkan bahwa terapi akupunktur dan hipnoterapi merupakan suatu terapi yang relatif aman dan efektif dalam mengatasi efek samping dari kemoterapi dan untuk meningkatkan kualitas hidup penderita kanker.

\section{METODE PENELITIAN}

Penelitian ini adalah penelitian kuantitatif, dengan jenis penelitian quasi eksperimental one group desain. Rancangan dalam penelitian ini dengan pendekatan model pendekatan subjek yang digunakan adalah cross -sectional.

Populasi pada penelitian ini adalah pasien kanker rahim yang ada di wilayah Surakarta, adapun intervensi penelitian di lakukan di Griya Sehat Prima Hati Surakarta . Jumlah sampel 14 orang yang sesuai dengan kriteria inklusi dan eklusi.

Instrumen yang digunakan dalam penelitian ini berupa kuesioner untuk menilai kualitas hidup menggunakan instrument dari Europen Organization for Research and Treatment of Cancer Quality of Life Questionnairre - Core 30 (EORTC QLQ-C30)

Pengumpulan data dilakukan dari bulan Juni sampai dengan November 2015. Responden yang memenuhi kriteria inklusi diberikan penjelasan tentang tujuan dan manfaat penelitian serta resiko yang mungkin dialami selama penelitian. Responden yang bersedia untuk ikut sebagai responden penelitian diminta menandatangani informed consent. Peneliti kemudian memberikan penjelasan kepada responden tentang cara pengisian kuisioner dan memberikan kesempatan kepada responden untuk bertanya apabila ada pertanyaan di dalam kuesioner yang kurang dimengerti oleh responden.

Data diambil pada saat sebelum dan setelah di lakukan tindakan Hipnopunktur, setelah data terkumpul maka data dideskripsikan dan diberikan skor. Dinyatakan kualitas hidup buruk jika skor $<500$, sedang jika skor $501-$ 1000, dan baik jika skor > 1000 (Felix et al, 2001). Selanjutnya data 
ditabulasikan. Dalam menganalisis pengaruh metode Hipnopunkture terhadap kualitas hidup pasien kanker rahim pasca kemoterapi , uji yang digunakan adalah $t$-test dengan bantuan komputerisasi. Tingkat kemaknaan atau kesalahan pada penelitian ini adalah $5 \%(\mathrm{p}<0.05)$

\section{HASIL PENELITIAN}

Data karakteristik responden yang dikumpulkan menunjukkan responden berada pada usia dewasa yaitu rentang usia 45 tahun - 60 tahun berjumlah 14 orang

( $100 \%)$. Responden kanker rahim pada stadium II, berjumlah 4 orang ( 28 $\%)$. Responden sebagian berada pada stadium III berjumlah 8 orang ( $57 \%$ ), Responden kanker rahim pada stadium IV berjumlah 2 orang ( $14 \%$ ). Setelah dilakukan pengukuran kualitas hidup pada responden hasil yang didapatkan sebagai berikut, hasil kualitas hidup sebelum di lakukan intervensi yaitu pasien dengan kualitas hidup buruk skor kurang dari sama dengan 500 berjumlah 7 orang (50\%), pasien dengan kualitas hidup sedang skor antara $501-1000$ berjumlah 7 orang (50\%) dan tidak didapatkan pasien dengan kualitas hidup baik. Hasil setelah intervensi hipnopunkture sebagai berikut pasien dengan kualitas hidup buruk skor kurang dari sama dengan 500 berjumlah 4 orang (28\%), pasien dengan kualitas hidup sedang skor antara $501-1000$ berjumlah 5 orang $(36 \%)$ dan pasien dengan kualitas hidup baik skor diatas 1000 berjumlah 5 orang ( $36 \%)$. Setelah dilakukan analisis statistic dengan uji $t$ (t-test) didapatkan nilai signifikansi $(\mathrm{p})$ $=0.000$ yang dibandingkan dengan nilai $\alpha=0.05(5 \%)$, dimana nilai $\mathrm{p}<$ 0.05 , sehingga $\mathrm{Ha}$ diterima dan $\mathrm{Ho}$ ditolak yang berarti bahwa terdapat pengaruh yang signifikan antara metode Hipnopunkture dengan peningkatan kualitas hidup. Nilai uji t didapatkan -0.824. Nilai tersebut berada diantara interval koefisien 0.8 1.0 yang menandakan tingkat pengaruh antar variabel tersebut sangat kuat.

\section{PEMBAHASAN}

Dari hasil pengamatan karakteristik responden berdasarkan umur, diperoleh data responden berada pada kategori usia dewasa. Hasil penelitian ini sejalan dengan data Riskesdas (2007) yang menyatakan bahwa angka kejadian kanker meningkat tajam mencapai 7 orang per 1000 penduduk setelah seseorang berusia 35 tahun keatas. Usia merupakan faktor mendasar lain dalam perkembangan kanker. Seiring bertambahnya usia maka terjadi akumulasi faktor resiko secara keseluruhan, kecenderungan mekanisme perbaikan sel menjadi kurang efektif seiring dengan penuaan dan penurunan system imun. Faktor - faktor inilah yang menyebabkan insiden kanker bertambah dengan bertambahnya usia (Kartawiguna,2002; WHO,2011). Angka ketahanan hidup juga akan mempengaruhi jumlah pasien kanker berdasarkan usia. Berdasarkan penelitian Sihombing dan Sirait (2007), angka ketahanan hidup di pengaruhi oleh stadium dan pengobatan kanker. Stadium kanker tentu akan berkembang bersamaan dengan bertambahnya waktu atau usia pasien sehingga menurunkan angka ketahanan hidup pasien. Hal ini mungkin menjadi salah satu faktor sedikitnya pasien kanker pada usia tua (65 tahun )yang ditemukan pada penelitian. 
Berdasarkan hasil pengukuran kualitas hidup pada responden diperoleh data sebagian besar responden sebelum dilakukan intervensi hipnopunktur kualitas hidupnya sedang \& buruk masing - masing $50 \%$. Dan tidak ditemukan kualitas hidup baik. Berdasarkan teori, penurunan kualitas hidup pada penderita kanker dipengaruhi oleh faktor yang beranekaragam seperti gejala, jenis perawatan yang diperoleh pasien, status penampilan pasien, depresi dan keyakinan spiritual (Kreitler et al, 2007)

Berdasarkan hasil pengukuran kualitas hidup pada responden diperoleh data sebagian besar responden setelah dilakukan intervensi hipnopunktur kualitas hidupnya buruk $28 \%$, sedang $36 \%$ \& baik $36 \%$. Terjadi peningkatan kualitas hidup responden. Hal ini sesuai dengan penelitian Burton et al (2010) yang menemukan bahwa pasien kanker memiliki kebutuhan tinggi terhadap tindakan yang menenangkan dan meningkatkan kondisi tubuhnya setelah tindakan kemoterapi. Tindakan hipnopunktur diperlukan untuk mengatasi masalah - masalah yang timbul akibat perubahan pada faktor fisik, psikologis dan sosial pada pasien kanker. Faktor fisik dipengaruhi gejala yang terjadi akibat penyakit kanker tersebut dan pengobatan yang diperoleh. Faktor psikologis dipengaruhi kecemasan atau depresi akibat rasa kehingan harapan, kehilangan kontrol dan kebebasan melakukan aktivitas. Sedangkan faktor sosial dipengaruhi oleh kesulitan sosial pada pasien kanker Hasil analisis metode hipnopunktur untuk peningkatan kualitas hidup pasien kanker menunjukkan ada pengaruh yang signifikan. Berdasarkan nilai koefisien korelasi $(r)$ dapat disimpulkan tingkat pengaruh antar variabel tersebut sangat kuat. Kualitas hidup sangat terkait dengan normalitas, termasuk fungsi normal atau kebutuhan minimal manusia yang harus terpenuhi. Menilai kualitas hidup dengan jelas dan menyeluruh membantu menentukan kapan harus memberikan tindakan hipnopunktur.

\section{KESIMPULAN DAN SARAN}

Hasil identifikasi karakteristik responden diperoleh semua responden berusia dewasa yaitu berusia 45 tahun 60 tahun. Hasil identifikasi kualitas hidup pada responden diperoleh data sebelum di lakukan intervensi yaitu pasien dengan kualitas hidup buruk skor kurang dari sama dengan 500 berjumlah 7 orang $(50 \%)$, pasien dengan kualitas hidup sedang skor antara 501 - 1000 berjumlah 7 orang $(50 \%)$ dan tidak didapatkan pasien dengan kualitas hidup baik. Hasil setelah intervensi hipnopunkture sebagai berikut pasien dengan kualitas hidup buruk skor kurang dari sama dengan 500 berjumlah 4 orang (28\%), pasien dengan kualitas hidup sedang skor antara 501 - 1000 berjumlah 5 orang $(36 \%)$ dan pasien dengan kualitas hidup baik skor diatas 1000 berjumlah 5 orang ( $36 \%$ ). Hasil analisis pengaruh metoda Hipnopunkture terhadap kualitas hidup responden menunjukkan bahwa terdapat pengaruh yang signifikan.

Metoda hipnopunktur mempunyai pengaruh yang signifikan sehingga diharapkan tindakan tersebut tetap diberikan pada pasien kanker.

\section{DAFTAR RUJUKAN}

Cohen,A.J., Menter, A., \& Hale, L. (2005). Acupuncture : Role in comprehensive cancer care-A Primer for the oncologist and Review of the Literature 
Integrative Cancer Therapies, 4 $1-13$

Felix, A.S., Cook, L.S., gaudet, M.M., Rohan, T.E., Schouten ,L.J.Setiawan, V.W., et al. (2013). The etiology of uterine sarcomas : apoled analysis of the epidemiology of endometrial cancer consortium. British Journal of Cancer, 108, $727-734$

Jin, Guan-Yin., Jin, Jia -Jia., \& Jin, Louis L. (2006). Contemporary Medical Acupuncture Systems Aprproach. Beijing : Higher Education Press.

Mahoney, S.E., Davis,J.M., Murphy,

E.A., Mc Clellan, J.L., Gordon,

B., \& Pena, M.M.(2013).

Efeects of 5 - fluorouracil chemotherapy on fatique: Role of MCP-1. Brain Behave Immun, 27(1), 155 -161

Naaman, Y., Shveiky,D., BenShachar,I., Shushan,A., MeijaGomez, J., \& Benshushan, A.(2011). Uterine Sarcoma : Prognostic Factor and Treatment evaluation. Israel Medical Association Journal. 13,76-79

Sugiyono, 2010. Metode penelitian Pendidikan ( pendekatan Kuantitatif, kualitatif dan R\&D) Alfabeta, Bandung.

Vinjamury S.P, Li J.T., Hsiao, E., Huang., C., Hawk., C., Miller, J., \& Huang, Y. (2013). Effects of acupuncture for cancer pain and quality of life - a case series. Chinese Medicine Journal, 8, 1-6

Spichiger,E., Muller- Frochlich, E., denhaerynck, K., Stoll,H., Hantikainen V., \& Dodd, M.(2001). Prevalence of symtoms, with a focus on fatique and changes of symtoms over three month in outpatients receiving cancer chemoterapy. The European Jornal of Medical Science, 1411-11

Witt, C.M., pach,D., Brinkhaus, B., Wruks, B., Tag, B., Mank, S., et all (2009), Safety of acupuncture : results of a prospective observational study with 229,230 patient and introduction of a medical information and concent form. Forsch Komplementmed,16, 91-97 